\title{
Appraisal of Perspectives to Morality in Business: Towards Developing Effective Operational Mindsets for Business Practitioners
}

\author{
Dr. Adeyeye Adewole \\ Department of General and Entrepreneurial Studies. \\ Ondo State University of Science and Technology \\ (OSUSTECH) Okitipupa, Ondo State Nigeria \\ Dr. Ginah 0. Ginah \\ Nigerian Content Development and Management Board (NCDMB) \\ Yenagoa, Bayelsa State, Nigeria
}

\begin{abstract}
The study critically examines available perspectives to morality in business. It observes that each of the perspectives to morality in business may seem plausible; the reality of business clearly indicates that morality is intrinsic in the purposes and existence of business. The study further observes that the functional activities of business are presupposedly subjects of moral value judgment. The study posits that efforts should rather focus on discussions and concerns on moral benchmarks for sustainable business practices in view of emerging socio-cultural and global dynamics. It concludes that appropriate synthesis of perspectives is the way to go in order to enhance business education among students and practitioners in Nigeria.
\end{abstract}

Keywords: Moral Perspectives, Business Ethics, Business Practitioners

INTRODUCTION

Business ethical analysis is an emerging thought-form in the field of applied ethics. It has continued to gain wider prominence. Its prominence is accentuated by business dynamics particularly with increased globalization of business and economic activities (Olusola .J. 2001). The fundamental principle that informs business ethical thought-form derives from the moral challenge which confronts every business. Aside from the fact that every business has become subject of moral analysis, individual businesses are being compelled to imbibe or exhibit the ethical practices in transactional activities. As a result of this, business ethicists, moral philosophers, cultural experts and practicing business managers have risen to the challenge posed by ethics in business. They have made series of effort to explain key factors that informs business ethical practices. Research attention also covers the various dimensions of business ethical practices as well as identification of key business ethical problems in practical term (Herbert J.I 1961). Efforts have also been made to establish the effects of business ethical practices on business performance and also develop the necessary link between ethical sensibility of business and the enabling geo-political and cultural milieu. This has led to the categorization of business in terms of socio-cultural cum national boundaries.

Unfortunately, there are pervasive arguments among philosophers and particularly business practitioners on the issue of morality in business. Traditionally, we have two sides to issue of moral status of business organization. We have those who uphold possibility and applicability of moral analysis in business organizational activities. The other side of the divide believes that business organization and its activities are outside the purview of moral analysis. On a 
balancing scale, the two positions seem reasonable, done to the fact both positions have good points. These studies consider each of the perspectives to morality in business. It went further to elucidate a mid-point so as to reconcile apparent contradictions in order to develop a realistic status of morality in business for effective practices by average business practitioner

\section{ARGUMENTS FOR MORALITY IN BUSINESS}

The argument in support of morality in business organization first and foremost sees morality as something that is clearly embedded in all levels business organizational activities. This view is part of the original position, which sees business as part of Gods' plan for man and his work (David P.W.F 1997). In the early part of $20^{\text {th }}$ century, Andrew Carnegie and Julius Rosenwald, two American business leaders pioneered the campaign for moral status of business organization. They upheld the original view, which sees business as part of God's plan for man. Both Carnegie and Rosenwald insist that it is virtuous for business organization to be committed to moral behaviour. To them, God want business organizations to do good so that people that run the business can also do well. It was on this understanding that Carnegie started the famous Carnegie Foundation which has donated generously to notable causes. To Carnegie and those people who believe in his business initiative, morality is crucial in business organizational behaviour. A business organization should be moral in its activities just like every moral human being. This position insists that moral life is part of Gods' plan for man and by extension to human business activities. Supporters of this school also see morality as essential business organizational behaviour in the wider context of social responsibilities requirements for normal business organizations.

Furthermore, morality is perceived as provisions of high quality products, educational enhancements programmes, health care delivery services, water supply and infrastructures to communities where business are located. It is their contention that if a business organization is located in an environment and the organization depends on environment for its resources and market, business has moral responsibility to contributes to the development of such environment. Acting morally in this sense is quite indispensable since the environment has acted magnanimously by making the environment conducive for business to operate. Therefore it is morally incumbent on business organizations to reciprocate the good gesture and co-operation it enjoys from the environment by acting morally through provision of beneficial programmes for its host communities. Morality in this sense demands that business organization should engage in social programmes and other palliatives projects such as provision of schools, sports, water supply, clearing up polluted water, providing jobs etc. By so doing, business organization will be at peace with community. It will also be in good harmony with its environment. On this very important point (Hugh F. 1998) observes that moral activities of business organizations are critical to maintaining its role and status in the society. This statement implies that moral acts are necessary on the part of business organization if they are to maintain cordial relationship with their host communities. It sees morality as the basis of mandatory interface between business and its host community. Various research studies have clearly indicated that business organization which does not care about its community as a result of 1immoral actions have had to suffer the consequences. (Aderson.E.1993) (Bainbrigde S.M. 2008) (Moriarty. J. 2016). Some of the possible consequences to which business organization may suffer due to involvement immoral activities include consumer resistance, product rejection and strained relationship (Carr.A.2 1968); (Attas. D. 1999), (Mason. A, 2017)

Another argument for moral status of business organization is the one that justify moral behavior as an indispensable path to future growth and sustainability. On this, Henry Ford II, the Chairman of Ford Motor Company observes that for a business organization to realize its 
full potential in the world of tomorrow, businesses and industries will have not make morality or social goals central to its decision-making (Henry F. 1978). In apparent justification of this contention, practical business field experience have shown that when business organizations exhibits high moral sensibility by committing themselves to integrity, producing credible and reliable goods, donate generously to worthy causes by supporting universities, sports or environmental developments, such business organizations are assured of continuous patronage that is necessary for growth and survivability. By implication, the greatest challenge of sustainability that confronts business organization is the moral duty to behave ethically (Caldwell. P 1998). The implication of this is that the future growth of business organization is predicated on its ability to behave morally. Business organizations face the needs to be moral, conscientious and considerate in its activities. A prolong patronage is the bedrock of sustainability while sustainable patronage is a necessary condition for business advancement both in terms of profitability, turnover and long term existence.

Although with our daily experience in Nigeria, it may seems ironic that most business organizations that engages in unethical practices ended up being prosperous more than those that does not engage in unethical practices. Being prosperous in this context is to acquire large financial gains through unethical activities such as kickbacks, over-involving, rip-offs, overpricing etc. Unethically acquired fat profits by business organisations can tactfully be used to secure future. Obviously because they thwart rules and this is very common in developing societies that places high premium on crude material accumulations. Nevertheless, one should also not lose sight of the fact that if there is any success attained by business organization through unethical practices, such success would be anything but short-lived. In contrast, the successes assured by morally sensitive business organizations are founded success on that is sustainable. It is a success that is self-assuring. Ethical business organizations enjoy absolute trusts. Trust in turn, brings about loyalty. A combination of trust and loyalty results in a durable, guaranteed and a mutually beneficial relationship, which is long lasting.

For another angle, the approach which upholds morality in business also insists that morality is inevitable to business activities. This is simply because morality gives interpretations to business existence. Accordingly, business organization must give morality its' pride of place so that business pre-occupation can be meaningful. Against this backdrop, businessmen and business organizations must stress the importance of personal and Organisational moral philosophy in order to give their work meaning (Sheed F and Ward 1963). Hence businesses are daily confronted with various ethical dilemmas such as moral obligations to pay taxes, need to maintain sound inter or intra transactional relationship, attention to public interest amongst other moral responsibilities. The way and manner a business organization is able responds to these dilemma will go a long way to determine the interpretation and type of meaning an organization portrays.

A business organization will be adjudged immoral if such organization is considered to have acted wrongly or very badly. An immoral organization will lose reputation, this apart from the risks of law suits, boycotts, government restriction all of which can endanger profit (David, Irwin \& Joyce 1967). An organization that acts rightly sends the signal of ideal meaning. Ideal meaning encompasses actions that send positive signals, and also demonstrate action worth pursuing by business organization. Ideal meaning is achieved by business organization when it gives scrupulous attention to the interest of the public and maintains trusting relationship with every institution that is involved with the firms' activates (Hartley R.F 1993).

Furthermore, proponents of morality in business also see moral issues as something very fundamental to business operations. A business organization according to this position has 
network of relationships with its consumers, the society, employees, shareholders, communities, government, regulatory authorities etc. The principle of network relationship presupposes that business organizations are morally responsible to the demands of each of this network of relations. For instance, a business organization is morally responsible to its consumers. To the society, it is the moral obligation of business organization to engage in activities that bring about good neighborliness such as involvement in community affairs. Employees are morally entitled to fair treatments in terms of fair wages and comfortable work environment. The shareholders are also morality obliged to fair return on their investments. These obligations are moral activities, which business organization must perform.

Finally, the pro-moral status of business organization has continually upheld new business orientation. The new orientation in business emphasizes demands of moral integrity, nobility, honesty, fair deal, accountability, transparency and honor from business organizational entities. This position believes that all things being equal, business entities are defacto moral embodiments. And as moral embodiments, business organisation should appropriately assume their role as moral agents that are liable to moral adjudication. Therefore all business organizations are expected to be morally awake. In line with this thought, business should have the consciousness to behave based on the moral duties and virtues arising from the principles about right and wrong (Josephson.M. 1993). Each programmes and activities of business must be adjudged rightly or wrongly depending on the morality of such action. In practical sense, businesses have often experienced alternating stage of low prestige and high prestige (David, Irwin \& Joyce 1967).

In conclusion, business activities are de facto embodiments of morality. This implies that business activities are subject of moral value judgments about moral intentions of business activities as well as consequences. The value judgment may also include principles and standards of ethical conduct that stems from organizational goals, responsibilities, human conscience, legal dictates and moral derivatives in order to determine whether which action of business is ethical or not.

\section{ARGUMENTS AGAINST MORALITY IN BUSINESS.}

At the other side of the divide there are those that deny the applicability of moral value judgment in business organizational behaviour. To this position, business organizations are peculiar entities, which cannot be subjected to moral value judgment. There are various angles to this position.

A major proponent of zero moral status of business organization is Prof Milton Friedman, a famous monetarist economist and Nobel Laureate. To Professor Friedman, the only reason why business exists is to make profit for its owners. Business organization does not have any other responsibility apart from profit objective except perhaps to respect the law of the land. While making profit, business is only obliged to respect the laws of the land especially if those laws are in public interest. Apart from respecting the law of the land, business organization has no other responsibility and should not be bothered by any other responsibility. It will be better for everybody if business concentrates on maximizing profit instead of being bothered by any other considerations (Friedman.M. 1963). Friedman is bitter and frowned at why business should spend its hard earned money on social development projects such as educational advancement projects, sport, physical infrastructures etc. To him, these are the responsibility of government and it is as if business organization is prying in an activity that does not concern it. If there were to be any moral consideration in the activities of business organization, Prof. Friedman asserts it should be in the context of the responsibilities of 
business organizations as to how they have been able to fulfill their profit maximization mandate.

The limitation of Friedman position is made manifest because of undue emphasis he placed on profit maximization. He believed erroneously that profit should be the sole determinant of business behaviour. This position seems to paint another picture of business organizations. It gives the impressions that business organizations are myopic, selfish, and uncaring. Although shareholders are entitled to higher return corresponding to the real chance they have to loose whole or part of their investment (Elegido.J. 1996), aside from profit considerations, we believe there is always be the need on the part of business organization to give considerations to the impact of their activities on people and institutions that are connected or affected by what they do. Consideration in this sense refers to the value of right attitude, duty, fairness and justice, which are necessary compliment to the fundamental profit objective of a business organization.

For those who are opposed to morality in business, they often use the issue of locus of moral responsibility in business organization as a ground to justify of their position. To them, there is elementary presupposition in moral value judgment, which states that an action can be said to qualify for moral appropriation when there is clear moral responsibility on the part of whoever is responsible. In other words, there should no argument as to who is responsible for an action. When that happens, the person who performs an action can then be morally adjudged. The issue of locus of responsibility is sacrosanct in moral value judgments. In the case of business organization, it seems there is a problem of who is actually responsible. For a business entity to accommodate moral approbation it must not be in doubt that business organization is properly responsible for the said action. This is necessary to prevent mis-directed or ambiguous moral value judgment. After all, moral judgment can only take place, if the action performed can be properly attributed to business as the true author of such action in strict sense of responsibility. Based on this understanding, this position affirms that there is problem of "proper responsibility attribution" in the activities of business organizations.

A business entity is made up of aggregates of mass of people working together in an organizational context. In a typical business organization, it is very difficult to locate the locus of moral responsibility. The manager as the chief executive officer only exists to galvanize the action plan that emanated from a cluster of shareholders, worker's field report, consumer demands, social value requirements and suppliers myriads of requests. In a situation like this, is difficulty to know who is actually responsible for business organizational activities in the actual sense of the word. Business in this sense is an imaginary entity. The whole idea of business entity being an imaginary construct is shaped by conflagration of various stakeholders. Therefore, it is not only impossible to attribute moral responsibility when the action of business is a product of many variables; it is also a difficult task to locate who is actually morally responsible for a particular action in organizational context.

Strictly speaking, locating the kernel of responsibility of every action is a pre-requisite to any meaningful moral value judgment. Without proper definition of responsibility status in moral analysis, it may be difficult to locate the object of moral value judgment. Moral value judgment is meaningful when the author of an action is properly identified with his action. In the context of business organization, the problem of who is actually responsible for organizational action is a recurring issue. For instance, there was a time in Nigeria when the Banking Industry was experiencing serious distress occasioned by various malfeasances; a proposal was forwarded to government to prosecute shareholders of banks' for their banks inefficiencies. This was a clear departure from the general believe that management is responsible for business 
organizational activities. So also between 1998 and 2018, 2,819 categories of employees were arrested for prosecution from among 69 business organizations suspected to be involved in international trade malpractices (Advance Fee fraud). These and other issues have persistently raised the issue of responsibility in business organizational context. Various efforts are being intensified by scholars and practitioners to define responsibility status of corporate stakeholders through the concept of corporate governance. Ideally, an organization should have an independent existence. This is a fact recognized by law. But in view of practical experience, how does one determine moral culpability in organizational context? When moral value judgment does takes care of business organization as an abstract entity without reference to stakeholders? When does value judgment cover the shareholders or the employees? When does it cover everyone (the organization and its stakeholders? What are the determinants of responsibility of each of these categories?

Another common reason often advanced to deny moral status of business organization is the one that see business entity is an imaginary construct that has no subsisting existence. To this position, business organizations are mere concepts. They are non-existence. At best, business organization exists only in the mind of people and law. As a non-existing "being", business organizations are figments of imaginations with abstract existence. Since business organization are not existing in the actual sense of the word, this position contends that business organization lacked the basic condition which an existing being should have in order to be capable of moral value judgment. A business organization according to this position lacked proper self-consciousness. Being an imaginary construct, its consciousness is only in the mind of those that construct it. They maintained further that very many people are involved in the affairs of business organization. If there is consciousness at all in business organization, it is awareness of people that actually makes up the organization.

We contend however, that while it is true that there are critical problem that surrounds the existence of a business organization in moral sense, there is also a sense in which business organizations can be said to exist as subsisting phenomenon. Business organizations are actual entities recognized by law. Business organizations also perform various actions. The actions performed by business organizations expose them as entities capable of willful, sensible and conscious action that are liable to moral value judgment. Far more importantly, the invention of corporate governance has generally allayed the fear of locus of moral responsibility in organizational center.

\section{A Critical Synthesis:}

\section{Applied Ethics and Business Interactive Behavior}

Given the above divergent positions, there is the challenge of appropriate determination of moral status of business organization. There is critical need to develop framework for proper definition of moral status of business organizations. This is against the backdrop existing divergent position to the issue. The purpose is to develop a new thought pattern paradigm shift for practicing businessmen and women. This is based underlying assumption that operating with a minimum moral décor is the surest way to sustainability. In the submission of the opposing views, it is gratifying to note that both positions recognize the reality of business phenomenon. Business organization is a phenomenon, it is the sum total of all activities involved in the production and distribution of goods, and services (Fubara B.A 1985).

As an organization, business undertakes various activities. Some activities in which business are involved in this regard include production, financing, purchasing, marketing and expanding. Business organisation is also an interactive means for controlling works and achieving objective through effective management of individual with a group. The purpose of 
coming together of individual is to achieve stated and known organizational objective. The objectives of business organization are the end towards which the enterprises are aimed. Usually there are various objectives which organization may pursue. Some of these may include profit maximization, growth maximization, sale revenue, maintenance of market share and good public relations. This fact about the nature of business on the face it is one of the major causes of confusions on the responsibility status of business organization. Although business organization is made up of many individuals who may have their own unique identity, but at the level of organization, the objectives, action plan, responsibilities and other consideration are reduced to one. The only objective at this point remains the action plan, responsibilities and other consideration which individuals needs to share within the context of such an subsisting organization.

Important also is the fact that business organization engages in activity .It engages in one form of activity or the other. The activities of business organizations are usually in line with stated objective as clearly defined by the organization. More often than not such activities have multiple effects on people and institutions, which are organizational "externalities". Business organizational externalities refer to those categories of people or institutions that are affected by its operations. Each of these category of people or institutions have vested interest in the activities of business organization. There are certain expectations which each of these people or institutions look forward to receive from business organization. Essentially, business organization is expected to act always within the context of the above networks of relationship. In so far as business organization cannot exists in isolation of these intervening interest groups which constitutes its externalities, there is no way business organization can close its eyes on the expectations of the networks of relations which arises out of this network of relationships.

Although most business organization do behave as if to suggest that they exists only for profit maximization and also behave as if they are answerable only to law which actually give rise to their existence, the aggregate social expectation from network relations forms the basis of moral analysis as to determine which action of business organization is bad and which one is good. Moral analysis is necessary in light of societal or general expectations from business behavioral activities. Ethics and moral standards goes beyond the prohibition of law and the language of thou shall not to the issue of duty and the language of should and should not......it concerns human duties and the principles on which these duties rests (Thompson 1990).

In this sense, it seems there is no way business organizations can avoid the searchlight of moral value judgment. Moral value judgments exist to determine the moral culpability of organizational activities in terms of duties and responsibilities to people and institutions that have vested interest in the activities of business organizations.

Business activities are corporate activities and as corporate entities they are designed by man to achieve a given objective. The effect of business activities on people within and outside of it is widespread and enduring. There is no gain saying the fact that ethical consideration is intrinsic in business systems. It has also been observed that the functional activities of business organizations are loaded with various ethical issues. Such issues continuously draw the attention of ethical analysis. It seems inconceivable that ethical analysis cannot afford to ignore the activities of business organization. This is because the activities provide test cases in applied ethical analysis. Ironically, most business organizations themselves see ethics as mere internal code of practice. Ethics is not merely an accepted internal practice inside industry or profession rather ethics deals with the rightness or wrongness of human activities in so far as these can be known by reason (Thomas G. 1963). 
Regardless of business types, each business organization involve in activities that involve production, finance, staffing, marketing and entrepreneurship. In most cases, business activities are vested in management team. Management represent the specific organ of business organization, which ensure that business discharge its duties in accordance with stated objectives. Management is very crucial to business organization. It is the duty of management to handles every activity in a business organization. This is probably why most people identify activity-related functions of business organization with the notion of management. Management is to a business organization what a driver is to a car. The management exists to ensure activities of business organizations are safely performed. Hence management is defined as a problem solving process to effectively achieve organizational objectives through efficient use of scarce resources (Chandan J.S. 1975). Following this line of thought, management is also seen as the responsibility which involve judgments and decision in determining plans, using data to control performance, progress against plans and the guidance integration, motivation and supervision of the personnel comprising the enterprises and carrying out its operation (Breech. E.F. 1975)

The key element in business management is the manager. Manager constitutes the point man for business activities. He is the embodiment of activities within a business configuration. The organizational requirement enjoins managers to accomplish duties through the instrumentality of subordinate and this put manager in a conspicuous position where activities of managers are easily discernible (Collins C. G. E \& Devana. A. M. 1992). The activities of managers are easily discernible as a result of the tasks which manager assigns. Manages assigns task to people and ensure that work is done through people. The corporate functional activities of business organization involve strategic activities which have long-term implications for overall existence of business organization such as product brand decision, location of business in a particular place, shareholders fund contributions etc. The marketing functional activities comprises of activities like market research needs assessments, consumer needs estimation, profit planning activities, product packaging activities, distribution channel selection, branding, publicity advertising, sales promotion etc. Production function includes product-planning activity, scheduling of services, facility layout, product design, material sourcing, labour input activity, production flow, quality control, equipment and plant activities. Personnel functional activities include job analysis, job description guidelines; manpower needs forecasting recruitment, personnel selection, placement, training, wage administration, health, safety, personnel retirement and management-employee communication activities. Financial activities of business organization include capital sourcing, capital expenditure, credit sales, credit control and other financial related activities. With all the above plethora of activities by business in an organizational context, it portends a radical view on moral status of business organization. If for instance, morality is about conduct that deals with activity or behaviour and how such activity or behaviour has conformed to moral laws and it follows then that business activities are liable to moral analysis. If morality is also about system of thinking that treats conducts or activities and the duty that are associated with it (Murray. J. H. 1908) there is no way business organizations can escape the searchlight of moral value judgment. The fact that business organization performs activities presupposes that its activities must be subjected to moral value judgment.

In practical terms, there are two approaches to deal with moral issues in business organization. First, the activities of business organizations can be subjected to moral analysis in a wider context. This entails looking at the morality of business activities as unique organizational activities within the context of organization and its network relationship. This approach has resulted in taking critical look at social responsibility of business activities. Social responsibility is define an intelligent and objective concern for the welfare of the society which 
restrain individual and corporate behaviour from ultimately destructive activities, no matter how immediately profitable and which leads in the direction of positive contribution to human betterment (Cook. T.\& Menleson 1977). With this definition, it is obvious that as social responsibility define the value of the society; moral value judgment in that context exists to gauge the momentum of these responsibilities by institutions. The second approach to morality in business activities stems from moral consideration in respect of specific functional activities by the management of business organization. The understanding of this approach is that each activity that is performed by business organizations through management has moral implications. For this reason, moral analysis is possible in each of the various activities performed by business organizations based on network of management functional activities. The management functional activities include corporate activities, production activities, finance activities, personnel activities and marketing functional activities. Take for instance moral analysis is possible in corporate activities that deal with decisions on organizational product, the source(s) of fund and also the location of the business in a particular area. Other activities that may appeal to moral analysis in production functions of business organization includes, desirability or other wise of product specification, issues of product quality and standard, factory lay out and its moral impact etc. In personnel function of business organization, moral analysis includes employment procedures, issue of right wages and salaries, health and safety, welfare services etc. With marketing function, the moral implication covers activities such as advertising, attitude of sales personnel, distribution channel, product packaging, morality of price discrimination and product promotion. Finally, in business finance function the implication for moral analysis covers source(s) of fund, credit activities and debt issue etc. In a wider context, if morality is all about question that queries the ideals of activities in light of what should be the case. (Omoreigbe. J.I. 1993), then, every activity where ever and whenever it is performed in the context of business operations is liable to moral value judgment. An inquiry into activities of business organization indicates that every activity performed by business organizations, has an underlying moral implication. In actual fact, each activity performed by business organization raise(s) one moral question or the other.!

\section{CONCLUSION}

Douglas Sherwin in his famous paper entitled "The Ethical Roots of Business System" published in 1983 by Harvard Business Review catalogued the imperative of morality in business organization. His focus was based on perspectives from business primary existence. The summary of Sherwin's contention is that ethics is tied into the purpose of business and the nature of the institution itself. Douglas Sherwin may not be faulted. This is simply because a critical anatomy of the phenomenon of business organization gives clear interpretation of morality as part and parcel of business organizational existence. Morality is embedded in the very essence of business organizations. There is moral implication in business primary existence. Morality is at the root of every business organization particularly when the major aim of business is to satisfy needs. Business is a means of satisfying human wants, (Ibekwe. 0 . 1998) and as a mean of satisfying human want, business organization is a vital organ of society that is responsible for providing the society with goods and services. The implication of this definition is that business organization exists to meet the needs of society. It seems plausible to imply that business organizations perform important duty of following up on the needs of society. Peter Drucker (1955) after ruminating on the essence of business organization asserts that business organizations create customers. The satisfaction of customer need is the foundation of business, and it keeps it in existence. Therefore, all business organizations are morally obliged to put in place adequate machinery and activities to meet consumer needs. This self-imposed duty of consumer needs satisfaction is an important moral responsibility on the part of business organization. Also of moral significance are the activities embarked upon by business organizations in other to satisfy such needs. Business organizations are therefore 
morally obliged to satisfy perceived needs in a way that is morally acceptable to the society. Off course, there are two ways to the morality of needs satisfaction. It is either the needs of customer needs are satisfied rightly or wrongly. The society at the end of the day, through its ethical value system, reserves the right to adjudge. The society owes it as a duty of adjudge the morality of businesses in their efforts at satisfying needs. In other words, critical moral issues are derivable from business practical activities.

The implication of this synthesis is that morality is embedded in the core objective of business. It is intrinsic in the purpose and the existence of business organization. Ethics is irretrievably tied to the nature and practice of business. The moral value of society guides the needs specification which business organization intends to satisfy. At the end of the day, the moral meanings which society gives to business activity is predicated on how business has attempted to satisfy the needs of the society. Concerns therefore should transcend beyond whether morality is applicable to business or not. The focus should focus on how ethics can be used to moderate business sustainability. Business mangers particularly young entrepreneur should operate above the dichotomy and accept ethical morality as part of exigencies in business practice in order to attain sustainability of operation.

\section{References}

Anderson .E. (1993) Value in Ethics and Economic Cambridge. M. A. Havard University Press.

Asolo Adeyeye A 2008 Ethical Univesalism, International Business and The Challenge of Global Moral Order. Ibadan, Unpublished PhD Thesis

Atlas.D. (1999) what's wrong with Deceptive Advertising Journal of Business Ethics 21 (1) 49-59.

Bambridge. S.M. (2008). The New Corporate Governance in Theory and Practice: New York Oxford University Press.

Boye Lafayettee. D. M. (1994) Chinese Etiquette \& Ethics in Business 2nd Winois, NTC Business Book.

Breech, E.F.C. 1975. The Principles and Practice of Management London, Longman Publishers

Cauldwell P. 1998 Developing Corporate Social Responsibility, Nigeria Daily Times November

Carr. A. Z. (1968) Is Business Bluffing ethical? Havard Business Review 46 (1) 143-153.

Chandan J.S. 1969 Management: Theory and Practice India, Vitas publishing Limited

Cook T and Melenson 1977 Androgynous Management: Key to Social Responsibility. Advanced Management Journal 3

Crane. A and Matten. D. Business Ethics, 8

David's, P.W.F, 1997. Current Issues in Business Ethics. London, Routtedge

David, Irwin and Joyce (1967) Organizational Behaviour: An Experimental Approach 47

Drucker, P. F.1968 : The Practice of Management London Heinemann Publishers Ltd.

Edward. P. 1969 Encyclopedia of Philosophy, New York Macmillan..

Elegido. T. M. (1996) Fundamental of Business Ethics: A developing country perspective, Nigeria, spectrum.

Elegido J. 1996 Fundamental of Business Ethics.206-241

Eliza, GCC \& Mary . A.D (1992). The Portable MBA, (Ibadan) Spectrum Book.

Etzion .A.(1998). The moral Dimension: Towards a new Economic New York. Free Press

Friedman, M. 1970. The Social Responsibility of Business is to increases profit New York, Times Magazine $13^{\text {th }}$ September.

Fubara. B.A, 1997 Business Management: Principles and Practices, Nigeria University Press Plc

Garrett, M.T. 1966. Ethics in Business. New York Application- Century - Craft.

Getz.K.A. (1990). International Code of Conduct; An Analysis of Ethical Reasoning. Journal of Business Ethics No 11. $915-920$ 
Adewole, A., \& Ginah, G. O. (2020). Appraisal of Perspectives to Morality in Business: Towards Developing Effective Operational Mindsets for Business Practitioners. Advances in Social Sciences Research Journal, 7(1) 24-34.

Hathey R.F. (1963) Business Ethics: Violation of Public Trusts New York John Wiley \& Son

Hartman . P.H. 1998. Perspectives in Business Ethics Boston Irwin/MCGraw Hill

Henry. F 1978, Is Social Responsibility A Dead Issue? Business and Social Review. 190

Hospers .J. (1982). Human Conduct Problem of Ethics. $2^{\text {nd }}$ Ed. New York, Harcourt Brace \& co.

Hospers. J. An Introduction to Philosophy Analysis. London Rutledge and Kegan Paul Limited.

Ibekwe. O.U. 1998: Modern Business Management 4

Josephson, M. 1993. Making Ethical Decision. Marina Del Rey. C. A. The Josepluson Institute of Ethics.

Mason.A (2017) Appearance, Discrimination and Reaction Quantification. Journal of Political Philosophy 25 (1) 48-71.

Moriarty. J. (2016) Business Ethics Stan ford Encyclopedia of philosophy, 17th Nov.

Murray. J.H. Ed. 1908 . An English Dictionary of Historical Principles Vol 4,

Olusola, J.O. 2001. Ethical Imperatives for Sustainable Growth in the 21st Century. Jiboku Ed. Sustainable National Development: Problems and Prospect. 6-15

Omoregbe J.I. 1993 . Ethics: A Systematic and Historical Study. 3 ${ }^{\text {rd }}$ ed. Lagos, Joja Educational Rearch and Publishers.

Rankin. John. 1995. Ethics and Religion. London Longman

Sheed F and Ward, 1963. Ethics in Business. New York Publishers

Sherwin 0. S.1983. The Ethical Roots of Business System, Havard Business Review. Nov/Dec

Thompson .A.A. \& Strickland. .J. 1990 Strategic Management concept and cases. Boston Richard limited. 